\title{
RESOURCE CONSERVATION AND RECOVERY ACT CLOSURE PLAN FOR THE Y-12 9409-5 TANK STORAGE FACILITY
}

February 1995

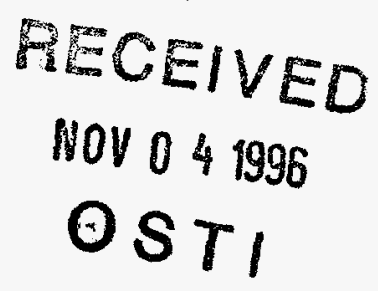

for

Environmental Restoration Division Oak Ridge Y-12

Oak Ridge, TN 37831-8247

Managed by

Martin Marietta Energy Systems, Inc. for the

U.S. Department of Energy

under contract DE-AC05-84OR21400 


\section{DISCLAIMER}

Portions of this document may be illegible in electronic image products. Images are produced from the best available original document. 


\section{DISCLAMER}

This report was prepared as an account of work sponsored by an agency of the United States Government. Neither the United States Government nor any agency thereof, nor any of their employees, makes any warranty, express or implied, or assumes any legal liability or responsibility for the accuracy, completeness, or usefulness of any information, apparatus, product, or process disclosed, or represents that its use would not infringe privately owned rights. Reference herein to any specific commercial product, process, or service by trade name, trademark, manufacturer, or otherwise does not necessarily constitute or imply its endorsement, recommendation, or favoring by the United States Government or any agency thereof. The views and opinions of authors expressed herein do not necessarily state or reflect those of the United States Government or any agency thereof. 
Y/ER-58 R.1

$\mathrm{Y}-12$

\section{OAK RIDGE \\ $Y-12$ \\ PLANT}

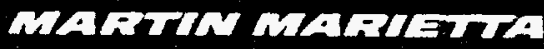

\section{RESOURCE CONSERVATION AND RECOVERY ACT CLOSURE PLAN FOR THE Y-12 9409-5 TANK STORAGE FACILITY}

February 1995

for

Environmental Restoration Division

Oak Ridge Y-12

Oak Ridge, TN 37831-8247

Managed by

Martin Marietta Energy Systems, Inc.

for the

U.S. Department of Energy

MARTIN MARIETTA ENERGY SYSTEMS, INC. 


\section{DISCLAIMER}

This report was prepared as an account of work sponsored by an agency of the United States Government. Neither the United States Government nor any agency thereof, nor any of their employees, makes any warranty, express or implied, or assumes any legal liability or responsibility for the accuracy, completeness, or usefuiness of any information, apparatus, product, or process disclosed, or represents that its use would not infringe privately owned rights. Reference herein to any specific commercial product, process, or service by trade name, trademark, manufacturer, or otherwise, does not necessarily constitute or imply its endorsement, recommendation, or favoring by the United States Government or any agency thereof. The views and opinions of authors expressed herein do not necessarily state or reflect those of the United States Government or any agency thereof. 


\title{
RESOURCE CONSERVATION AND RECOVERY ACT CLOSURE PLAN FOR THE Y-12 9409-5 TANK STORAGE FACILITY
}

February 1995

\author{
for \\ Environmental Restoration Division \\ Oak Ridge Y-12 \\ Oak Ridge, TN 37831-8247
}

Managed by

Martin Marietta Energy Systems, Inc.

for the

U.S. Department of Energy 


\section{CONTENTS}

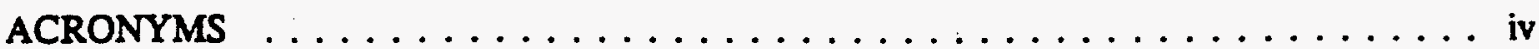

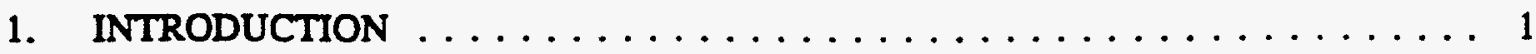

1.1 FACILITY DESCRIPTION $\ldots \ldots \ldots \ldots \ldots \ldots \ldots \ldots \ldots \ldots$

1.2 CLOSURE HISTORY $\ldots \ldots \ldots \ldots \ldots \ldots \ldots \ldots \ldots \ldots \ldots$

2. CLOSURE PERFORMANCE STANDARD $\ldots \ldots \ldots \ldots \ldots \ldots \ldots$

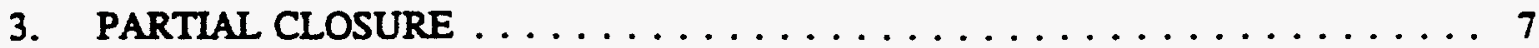

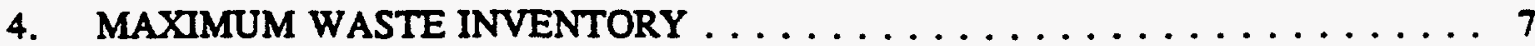

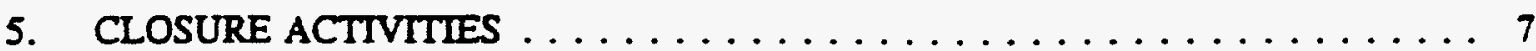

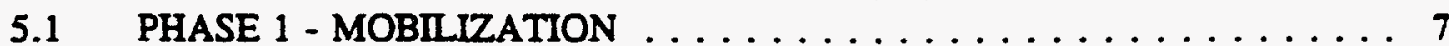

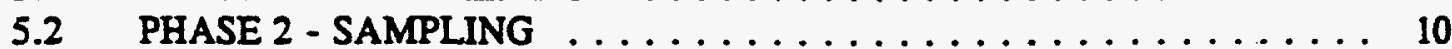

5.3 PHASE 3 - DECONTAMINATION AND CERTIFICATION . . . . . 10

5.4 PHASE 4 - POSTCLOSURE CARE ............... 11

6. SCHEDULE ............................ 11

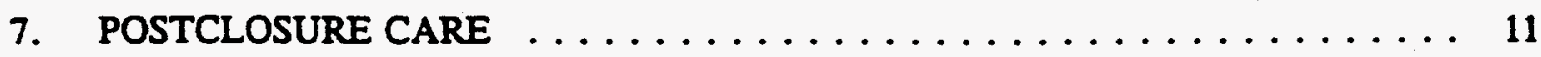

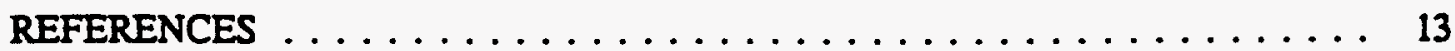

APPENDIXES

A SOIL SAMPLING AND ANALYSIS PLAN FOR THE $9409-5 \ldots \ldots \ldots \ldots \ldots$ 


\title{
ACRONYMS
}

\author{
BMP best management practices \\ CERCLA Comprehensive Environmental Response, Compensation, and Liability Act \\ DOE \\ DWS \\ U.S. Department of Energy \\ EPA \\ U.S. Environmental Protection Agency \\ ESPQCP \\ MCLs \\ PCBs \\ PID \\ ppm \\ QA \\ QC \\ RCRA \\ TCLP \\ TDEC \\ VOCs \\ Environmental Surveillance Procedures, Quality Control Program \\ maximum contaminant levels \\ polychlorinated biphenyls \\ Photoionization Detector \\ parts per million \\ Quality Assurance \\ Quality Control \\ Resource Conservation and Recovery Act \\ toxicity characteristic leachate procedure \\ Tennessee Deparment of Environment and Conservation \\ volatile organic compounds
}




\section{INTRODUCTION}

This closure plan has been prepared for the 9409-5 Tank Storage Facility (S-017) at the Oak Ridge Y-12 Plant. This plan outlines the actions required to achieve the closure of the S-017 facility and is being submitted in accordance with TN Rule 1200-1-11-.05(7) and 40 CFR Sect. 265.110. The 9409-5 facility has been used to store mixtures of liquid wastes containing spent solvents, and radioactive materials, and may have contained polychiorinated biphenols (PCBs).

This closure plan outlines the steps that will be taken to meet the closure performance standards specified in TN Rule 1200-1-11-.05(7)(a) and 40 CFR Sect. 265.11.

\subsection{FACIITTY DESCRIPTION}

The 9409-5 Tank Storage Facility (S-017) consists of a Resource Conservation and Recovery Act (RCRA) concrete diked area located in the southeast portion of the Oak Ridge Y-12 Plant (Fig. 1).

The diked area was originally constructed for cooling towers that were installed in 1942. However, the cooling towers became obsolete and consequently were taken out of service and dismantled.

The diked area was modified and placed back in service in 1980 . It was used as a two-compartment containment structure for above-ground storage tanks containing RCRA-regulated liquid coolant and waste oil/solvent mixtures (cells 1 and 2). A partiaily contained area was used as a temporary storage area for drums and 600-gal portable tanks (cell 3). In addition, just north of the cooling tower basin structure is a sump that receives stormwater overflow from the containment dike (cell 4). Four 5700-gal tanks were located in cell 1 to store liquid coolant. In 1982 two 30,000-gal tanks were installed in cell 2 for the storage of waste oil, possibly contaminated with PCBs, and solvent mixtures. In 1985 two 10,000-gal tanks were installed in cell 2. One of these storage taniks was for waste oil spent solvent mixtures which differed from the waste in the larger tanks. The other tank was dedicated to long-term storage of waste oil solvent mixtures containing greater than $32 \mathrm{pCi} / \mathrm{g}$ of uranium and greater than $5.0 \mathrm{ppm}$ beryllium.

All of the facility structures have been designated as a regulated RCRA unit(s) and will be closed as such. However, the only areas in which hazardous waste was stored are cells 1 and 2 . All of the tanks and associated piping have been decontaminated and removed from the area.

The hazardous constituents stored in the tanks included, chlorinated and nonchlorinated solvents, beryllium, and waste oil solvent mixures containing perchloroethylene, methylene chloride, 1,1,1-trichloroethane, and trichlorotrifluoroethane, and may have included PCBs. In 


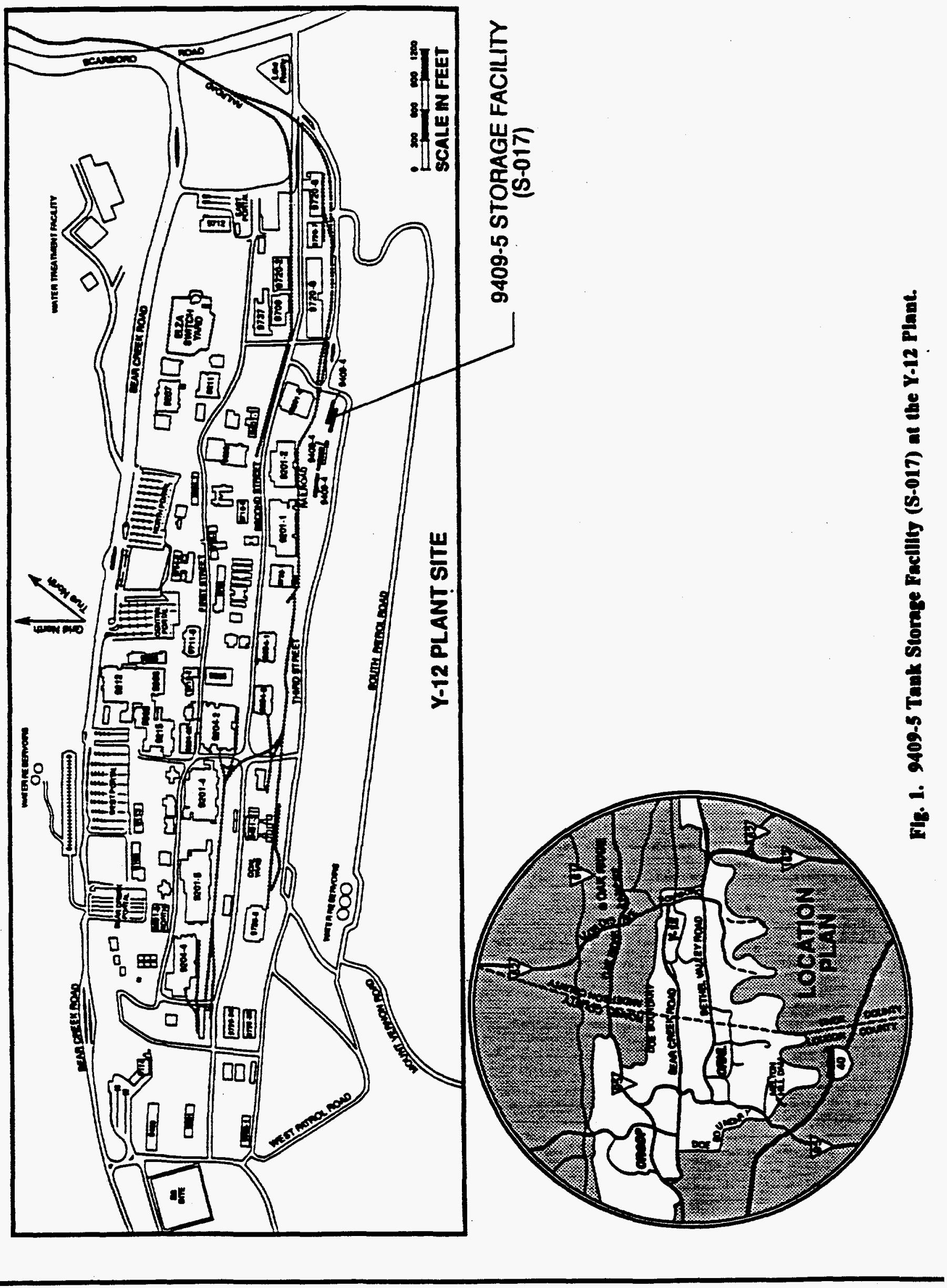


addition, chromium has been identified as a possible contaminant from previous cooling tower operations.

Preliminary sampling of the soils on the north and east sides of cell 1 and 2 and the north side of cell 4 adjacent to the containment structures has been performed. The investigation involved drilling in 10 locations to a depth of $5.5 \mathrm{ft}$ with a little beaver auger and obtaining samples at this depth (Fig. 2). Analysis results are presented in Table 1. More specific preliminary sampling information can be found in Preliminary Soil Sampling and Anatysis for the 9409-5 Storage Facility (S-017) (Stone 1989).

\section{CLOSURE HISTORY}

The 9409-5 facility was taken completely out of service in 1991. All tanks have been steam cleaned and removed. The concrete secondary containment structure was aiso decontaminated by steam cleaning when the last tanks were removed. The decontamination activities conducted at the time of decommissioning addressed all portions of the tank system. The remaining closure requirements consist of the sampling of soils below and surrounding the 9409-5 facility for purposes of determining whether contaminant release occurred. These activities are discussed further in Sect. 5.

\section{CLOSURE PERFORMANCE STANDARD}

The closure performance standard for the 9409-5 Tank Storage Facility may require the removal of any accumulated rainwater in the containment structures. All eight tanks have been previously steam cleaned and removed from the storage area. In addition, the concrete containment area was steam cleaned. These activities resulted in the removal of hazardous waste and hazardous waste residues from the facility.

The postclosure plan in Sect. 7 will be implemented if sampling around the storage facility measures contaminant concentrations above the levels specified in Table 2. Closure performance standards for soils are listed in Table 2. These levels are intended to protect human health and the environment. If analysis of soil samples show that these criteria are met the facility will be deemed closed. 


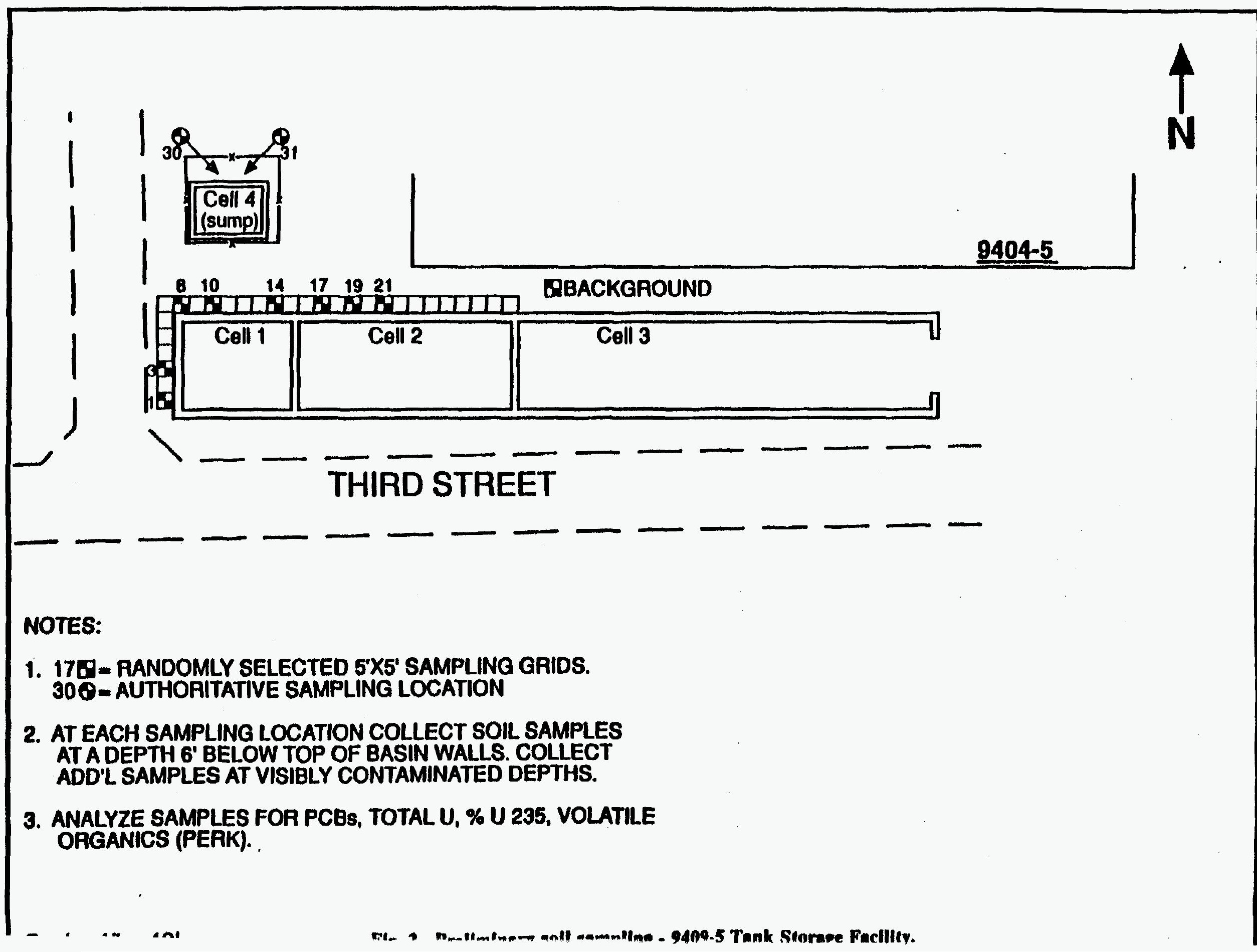


Table 1. Summary of preliminary soil analytical results for the 9409.5

Tank Storage Facility

Sampiing parameter

Uranium activity

(pCi/g)

Total PCBs

(ug/g)

Methyiene chloride (ug/kg)

Tetrachloroethane

(ug/kg)

Acetone

(ug/kg)

\section{Maximum value}

(sampling location)
Minimum value (sampling location)
0.28 (10)

ND (all)

144 (19)

13 (14)

244 (3)
0.12 (14)

$14 \quad(3)$

ND $(8,31)$

ND $(30,31)$

- estimated value 
Table 2. Parameters, procedures, and establisbed cleanup levels"

Parameter

Method

Cleanup Level

Metals: Chromium VI

TCLP

5 mg/kg

VOC: Methylene chloride" Tetrachloroethane Acetone

Methyl ethyl kezone'

Perchloroethyiere"

1,1,1-Trichloroethane

Trichlorotrifluoroethane

SW 8240

SW 8240

SW 8240

SW 8240

SW 8240

SW 8240

SW 8240

5000 mgkg

$35 \mathrm{mg} / \mathrm{kg}$

8000 mg/kg

$4000 \mathrm{mg} / \mathrm{kg}$

$800 \mathrm{mg} / \mathrm{kg}$

$7000 \mathrm{mg} / \mathrm{kg}$

$20,000 \mathrm{mg} / \mathrm{kg}$

PCBs

SW 8080

25 mg/kg

Table 2 bas been compiled from prevousty establisbed and approved information from the most receat regulatory standards and guidance.

Acrooyms: DWS - drinting water standard

TCIP - torody characterstic leachare procedure

VOC - volatile orgaure compound

Source: $\quad$ EPA 1989

EPA 1990 


\section{3. partial closure}

No partial closure is planned. Final closure of the $\mathrm{S}-017$ facility will be performed as described in this document.

\section{MAXIMUM WASTE INVENTORY}

The total volume of the tanks used to store hazardous waste in the 9409-5 Tank Storage Facility was $102,800 \mathrm{gal}$. No wastes are currently stored at this unit.

\section{CLOSURE ACTIVITIES}

All waste stored in the Tank Storage Facility has been removed. The tanks and piping have been decontaminated and removed. Closure activities for the 9409-5 Tank Storage Facility will be conducted in the following phases and steps (see Fig. 3).

\subsection{PHASE 1 - MOBILIZATION}

The mobilization phase will consist of verification of previous decontamination and removal actions and preparation of the site for closure activities. The actions under this phase will include, but not be limited to, the following:

- visit the site to assure tank, waste, and piping removal and determine extent of rainwater accumulation;

- survey the site for health and safety purposes;

- determine accessibility of the facility to sampling equipment; and

- identify sampling locations (Fig. 4) and mark locations. 


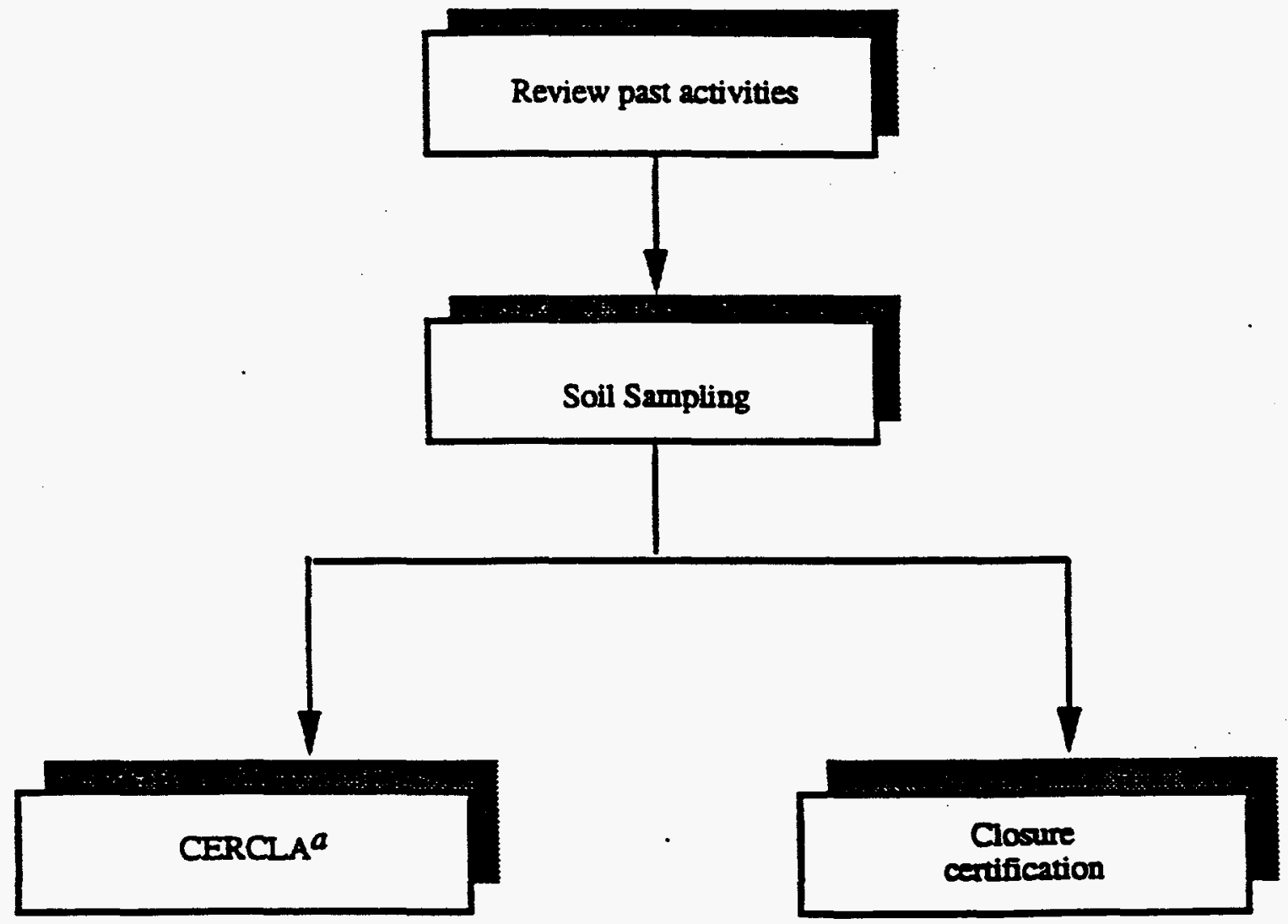

a CERCLA - Comprehensive Environmental Response, Compensation, and Liability Act.

Fg. 3. Closure plan decision flowchart for the 9409.5 Tank Storage Frellity (S-017). 


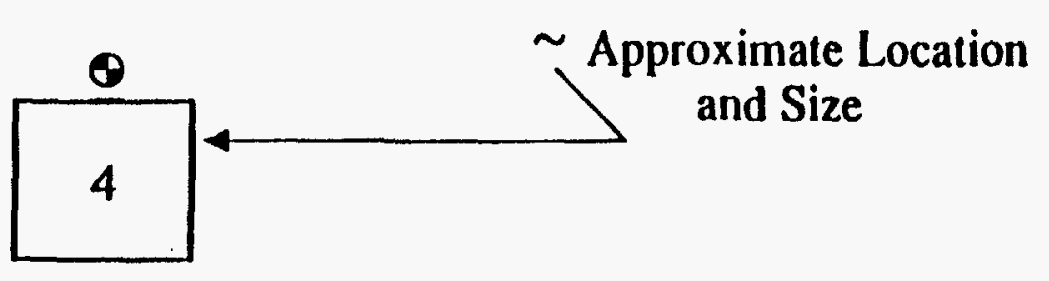

0

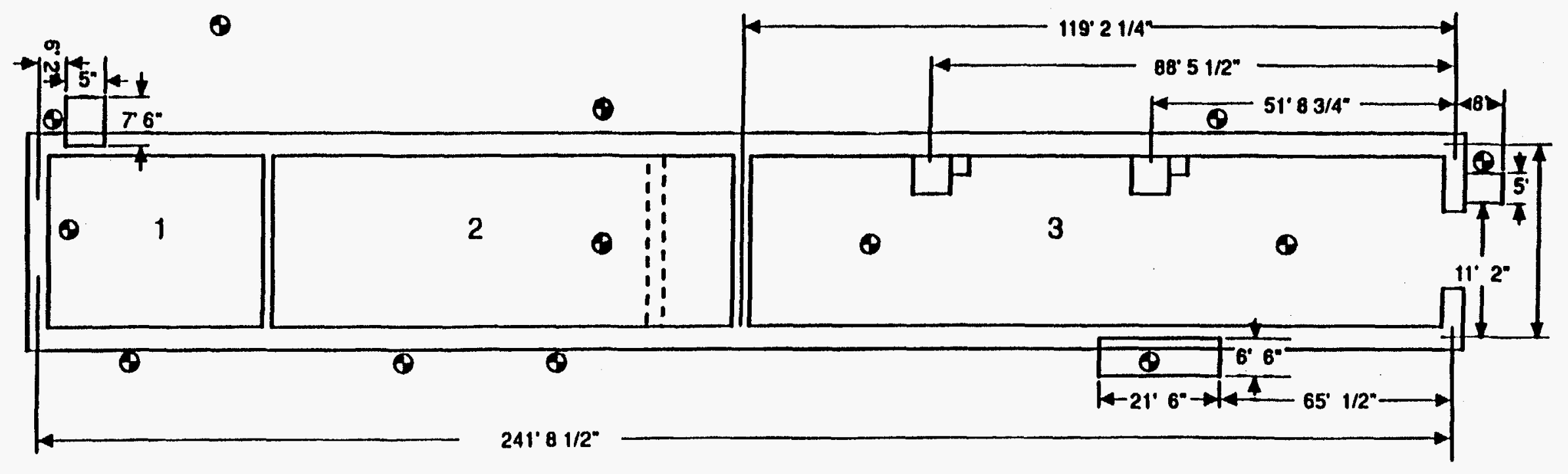

Legend:

- Boring Locations 


\subsection{PHASE 2 - SAMPLING}

The sampling phase will consist of soil sampling to determine whether environmental media at the unit have been effected by operation. This phase will be conducted in accordance with Soil Sampling and Analysis Plan in Appendix A. The following steps will be performed during this phase.

1. Sample and analyze accumulated rainwater (if present). Previous samples of rainwater accumulated within the secondary containment have not exhibited contamination. If no contamination is found the liquid will be discharged. If the samples indicate the rainwater is contaminated the water will be disposed of in accordance with standard plant procedures in an appropriately permitted facility or offsite.

2. Initiate soil sampling in and out of the diked area. Best management practices (BMP) will be exercised to ensure potentially contaminated material does not escape the sample or site area.

3. Decontaminate drilling equipment between drilling locations and obtain rinsate samples for analysis. At the completion of each day, pack samples for shipment to the anaiytical laboratory following proper procedures.

\subsection{PHASE 3 - DECONTAMINATION AND CERTIFICATION}

The decontamination and certification phase will consist of sample analysis evaluation and subsequent actions necessary to fulfill the closure objectives. The following steps will be performed during this phase.

1. Soil sampling analytical results will be reviewed. If contamination above cleanup levels is found at any location, the postclosure care activities outlined in Sect. 7 will be implemented. If the soil samples are not contaminated above cieanup levels, the facility will be closed without implementation of the postclosure care provisions for the surrounding area.

2. A closure certification package will be prepared based on the activities described above. Any area found to be contaminated after these steps are completed will be subject to the postclosure care requirements. The owners and operators of the 9409-5 Tank Storage Facility will submit a closure certification, in writing and by registered mail, to the Tennessee Department of Environment and Conservation (TDEC) Commissioner within 60 days of final closure. This certification will verify that closure has been completed in accordance with the required closure pian. The certification will be signed by the owner or an authorized representative and an independent registered professional engineer. 


\subsection{PHASE 4 - POSTCLOSURE CARE}

If soil sampling indicates that the contaminants listed in Table 2 are not present, or, are present at concentrations below closure standards, after the above activities are completed the unit will be deemed clean closed, and postclosure activities will not be implemented. Should any of these contaminants be found in concentrations above the specified cleanup levels, the postclosure care section of the closure plan will be implemented.

\section{SCHEDULE}

The closure activities associated with the 9409-5 Tank Storage Facility shall be conducted in accordance with the closure schedule found in Table 3. These activities may exceed the 180 days allowed by the regulations found at TN Rule 1200-1-11-.05(7)(d) and 40 CFR Sect. 265.113. The additional time for closure will be required only if further decontamination activities occur.

\section{POSTCLOSURE CARE}

Contamination of the environment above closure performance standards from the activities associated with the operation of the 9404-5 Tank Storage Facility is not expected. However, should contamination of the surrounding media be found, the U.S. Deparment of Energy (DOE) proposes to conduct any investigatory or remedial actions necessary under the authority of the existing Federal Facilities Agreement between DOE, TDEC, and the U.S. Environmental Protection Agency (EPA). Subsequent investigations or other pertinent environmental activities will be conducted by the Environmental Restoration program as a part of the ongoing CERCLA activities at the $\mathrm{Y}-12$ Plant. These actions will be conducted (if required) in lieu of the requirements found in 40 CFR Sect. 265.117 and TN Rule 1200-1-11-.057(h). 
Table 3. Closure schedule

Activity

Days required

Cumulative completion time - days

Phase 1 Mobilization

2. Preliminary site visit and

Health and Safety Plan development

15

15

b. Identify sampling locations and

prepare site for sampling

10

25

Phase 2 Sampling

2. Sampling of secondary containment and soil sampling

b. Sample anatysis

60

130

Phase 3 Decontamination and Certification

2 Review sample analysis

10

140

b. Prepare closure Certification Paclage

40

180

c Certify closure"

'Days elapeed depends upon decontamination activities. 


\section{REFERENCES}

Energy Systems (Martin Marietta Energy Systems, Inc.) 1986. Martin Marietta Energy Systems Environmental and Effluent Analysis Manual, Oak Ridge, Y-12 Plant, Oak Ridge, Tennessee.

EPA (U.S. Environmental Protection Agency) 1982. Test Methods for Evaluating Solid Waste (SW-846), July.

EPA 1989. RCRA Facility Investigation (RFI) Guidance, Vol. I of IV, EPA 530/SW-89-031.

EPA 1990. 55 Federal Register, page 30798, Corrective Action for Solid Waste Management Units at Hazardous Waste Management Facilities, July 27, 1990.

EPA 1992. Code of Federal Regulations. 40 CFR 261.25 "Toxicity Characteristic."

Stone, J.E. 1989. Preliminary Soil Sampling and Analysis for the 9409-5 Storage Facility (S-017), Y/TS-545, Oak Ridge Y-12 Plant, Oak Ridge, Tennessee, September. 
APPENDIX A

SOIL SAMPLING AND ANALYSIS PLAN FOR THE 9409-5 TANK STORAGE FACILITY (S-017)

AT THE Y-12 PLANT 


\section{PURPOSE}

The purpose of this plan is to outline a sampling and analysis program to accomplish the following directives: (1) determine if the inner diked area is contaminated, (2) determine whether contamination of the soil surrounding the facility has occurred, (3) determine the lateral and vertical extent of contaminated soil, (4) provide a baseline for aid in determining the type and method of remediation, if any, and (5) establish compliance with all federal and state regulations regarding residual soil contamination.

\section{RATIONALE}

The sampling program for closure of the 9409-5 Tank Storage Facility will be undertaken in a phased approach:

- Mobilization Phase. Preliminary site examination and preparation.

- Sampling Phase Task 1. Suspected and remaining waste characterization.

- Sampling Phase Task 2. Installation and sampling of nine borings outside the storage facility at predetermined locations (Fig. A.1).

The objective of this phased approach is to systematically determine the presence or absence of contamination in and adjacent to the 9409-5 Tank Storage Facility.

Mobilization Phase, preiiminary site examination and preparation, will be undertaken (1) to determine the accessibility of the storage facility and surrounding area, (2) to identify the existence of obvious contamination for suspect area investigations, and (3) to locate and mark the boring locations.

Sampling Phase 1, suspected and accumulated waste (rainwater) characterization, removal, and disposal, will be performed (1) to characterize and quantify any accumulated waste, (2) to remove the waste (if necessary), and (3) to eliminate the potential for accidental releases.

Sampling Phase 2, boring installations inside and outside of the diked area, will be performed (1) to determine whether soil contamination exists at the storage facility, (2) to determine the lateral and vertical extent of contamination, and (3) to provide baseline data for remediation. Sampling of equipment decontamination wastes will be taken for analysis as well. 


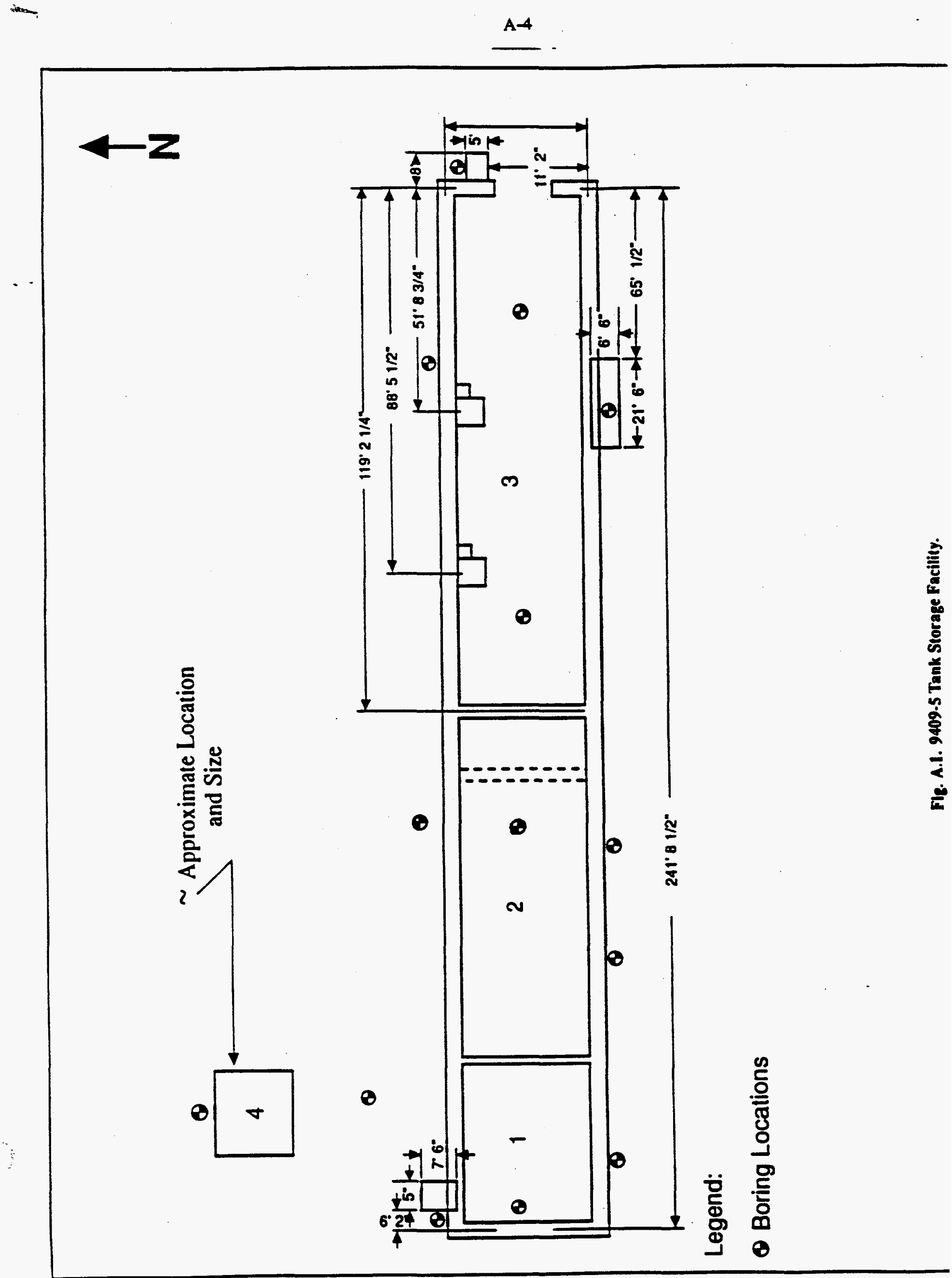


Mobilization Phase. Preparatory site inspection.

Sampling Phase 1. Suspected and accumulated waste characterization, removal, and disposal will be performed (1) to characterize and quantify any accumulated (rainwater) waste contained in the containment cell, (2) to remove the waste before the removal of the two tanks and cell walls (if necessary) prior to Sampling Phase 2, and (3) to eliminate the potential for accidental releases of contaminants to the environment.

Sampling Phase 2. Soil samples will be obtained from the boring locations shown in Fig. A.l. This sampling plan was based on the operations of the facility and on the EPA SW-846 sampling techniques for tanks and as specified by the Environmental Restoration Procedures of Martin Marietta Energy Systems, Inc. As these samples are taken, they will be placed in the appropriate sample container, tagged, sealed, bagged, and placed in an environment that will keep them at $4^{\circ} \mathrm{C}$. Chain-ofcustody procedures will be maintained throughout sampling, handiing, and storage. Soil samples will be taken from 0 to 6 in. and every 6 in. thereafter to 18 in. below existing grade and every $5 \mathrm{ft}$ thereafter to a depth at which groundwater is encountered or auger refusal is reached. Those parameters to be anaiyzed are contained in Table A.l along with the analytical procedures and maximum concentration levels. All samples will be analyzed in accordance with the appropriate test method as prescribed by EPA or other regulatory agencies and shown on Table A.1. TCLP analysis for chromium is only required if total chromium levels are greater than $100 \mathrm{ppm}$ by analysis method 6010 .

Quality Assurance/Quality Control (QA/QC). To ensure that appropriate QA/QC procedures are followed, trip and field blanks, equipment rinsate samples, and field duplicates will be obtained according to Table A.2. 
Table A.1. Parameters, procedures, and established cleanup levelse

Parnmeter

Metals: Curomium VI

VOC: Methylene chloride"

Tetrachloroethane

Acetone'

Methyl ethyl ketone"

Perchloroetbylene"

1,1,1-Trichloroethane"

Triehtorotrifluoroethanes
TCLP

SW 8240

SW 8240

SW 8240

SW 8240

SW 8240

SW 8240

SW 8240
Cleanup Level

\section{5 mgeks}

5000 menks

35 meskg

8000 mgkkg

4000 melks

800 mefls

7000 mgles

$20,000 \mathrm{mg} / \mathrm{ks}$

PCBs

SW 8000

$25 \mathrm{mg} / \mathrm{kg}$

Table 2 bas been compiled from previousty earublisted and approved information from the mat recent regutarory scanderts and guidence.

Acrodyese DWS - drinting water standard

TCIP - toricity charecterivic kenchase procedure

VOC - volntile organic compound

Source: EPA 1989

EPA 1990 
Table A2. Field quallty coatrol samples per sampling event

Type of eniple

Metal Organic

Trip blank

N/A*

1/cooler

(for volatiles only)

Equipmeat rinsute"

Idiny

1/ay

Field blank

1kourcerevent for all levels and all ancityes

Field duplicatest

$10 \%$

$10 \%$

NA - soc applicatie

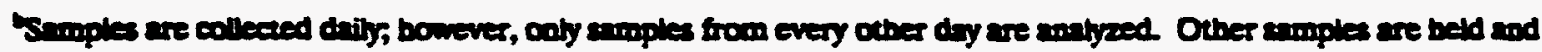
annlyed ooly if evidesec of contamination exies.

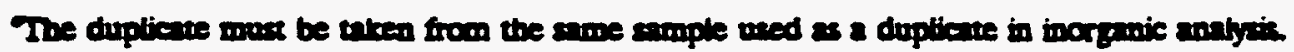

